\title{
FUNDACJA OPACTWA BENEDYKTYNŌW W STARYCH TROKACH
}

U progu XV stulecia na terenie świeżo erygowanej diecezji wileńskiej założono klasztor benedyktyński. Powstał on w Starych Trokach, w centrum ojcowizny Kiejstutowiczów, nieopodal nowej zamkowej rezydencji wielkiego księcia Witolda. Przez całe stulecie była to jedyna placówka tego zakonu na Litwie ${ }^{1}$. W niniejszym szkicu pragnę jedynie przypomnieć okoliczności tej fundacji i funkcjonowanie klasztoru za życia fundatora - wielkiego księcia Witolda, tj. do r. 1430.

\section{FUNDATOR I DATA FUNDACJI}

Zasługę fundacji benedyktynów w Starych Trokach dzieli Witold z opactwem tynieckim. Wolę fundacji wyraził wielki książę litewski, a jej przeprowadzenia dokonał dzięki zgodzie i udziałowi opactwa w Tyńcu, które utworzyło w Trokach zależne od siebie filialne opactwo obsadzone przez polskich mnichów ${ }^{2}$. Uznanie dla Witolda, jako kolatora opactwa, benefaktora i troskliwego opiekuna, zachował $\mathrm{w}$ historiografii benedyktyńskiej XVII-wieczny dziejopis tyniecki o. Stanisław Szczygielski. Przypomniał on także o specjalnej czci kommemoracyjnej, jaką żywili w liturgii wypominkowej wobec fundatora mnisi troccy ${ }^{3}$. Szczygielski zwrócił też uwagę na lokalizację klasztoru w ścisłym dworskim kręgu fundatora - na terenie starego zamku ojczystego (,,in arce patria pervetusta") Starych Trok ${ }^{4}$, choć rolę stolicy księstwa, a od r. 1413 województwa trockiego przejęły pobliskie Nowe Troki i nowy zamek Witolda.

${ }_{1} \mathrm{~T}$. Krahel, Kościót katolicki na Litwie na przełomie XV $i$ XVI w., „Analecta Cracoviensia" 16 (1984) s. 46.

2 J. Kłoczow ski, Zakony na ziemiach polskich $w$ wiekach średnich, [w:] Kościół $w$ Polsce, t. 1, Kraków 1966, s. 499; J. Kowalczyk, P. Sczaniecki, Benedyktyni w Polsce, [w:] Encyklopedia katolicka, t. 2, Lublin 1976, s. 242 .

s S. Szczygielski, Tinecia seu historia monasterii Tinecensis ordinis $s$. Benedicti, Kraków 1663, s. 252 n.; tenże, Series et notitia Trocensium abbatum ordinis S. Benedicti, Kraków 1668, przy biogramie pierwszego opata.

${ }^{4}$ S. Szczygielski, Series...; tenże, Aquila Polono-Benedictina, Kraków 1663, s. 117 . 
Zwracano już parokrotnie uwagę, że opactwo tynieckie, w przeciwieństwie do świętokrzyskiego, nie budziło zainteresowań benefaktorskich Jagiełły, zyskało natomiast sympatię Witolda ${ }^{5}$. W owym czasie, za rządów opata Mścisława (1386-1410), kanonika katedry krakowskiej, pozostawało nade wszystko $\mathrm{w}$ ścisłej więzi z biskupem krakowskim Piotrem Wyszem (1392-1412) ${ }^{6}$. Otóż u źródeł powołania klasztoru w Trokach odnajdujemy trzech ludzi: wielkiego księcia, opata i biskupa. Pierwszego z nich i ostatniego dzielił rosnący i coraz gwałtowniejszy konflikt. Biskup Piotr Wysz, jeden z najbliższych doradców Jadwigi, był zdecydowanym zwolennikiem realizacji programu pełnej i szybkiej inkorporacji Litwy do Korony Królestwa Polskiego ${ }^{7}$. Witold konsekwentnie dążył do zachowania całkowitej suwerenności Wielkiego Księstwa. Mimo jednak zdecydowanie różnych celów politycznych, biskup krakowski, jako zwierzchnik opactwa tynieckiego i protektor opata Mścisława, poparł plan instalacji polskiej placówki kościelnej na ziemi trockiej. Dla opata Mścisława był to z kolei płodny skutek uznania dla pomyślnie reformowanego wówczas klasztoru tynieckiego, wzrostu jego prestiżu w dobie sporu o prymat pośród opactw benedyktyńskich w Polsce. Mścisław starał się o realizację synodalnych postanowień biskupa Wysza z lat 1392-1396, przywracających ład i dyscyplinę pośród benedyktynów diecezji krakowskiej. Jako kanonik krakowski współdziałał z Wyszem w wielu innych sprawach diecezji, towarzyszył mu w podróżach na Sobór Pizański i do Ziemi Swiętej. Mnichów tynieckich kierował do Akademii Krakowskiej, pozostającej pod urzędową opieką biskupa ${ }^{8}$. Reforma Wysza, choć tak krótkotrwała, postulowała nowy model wspólnoty benedyktyńskiej: zrzeszenie opactw poprzez doroczną kapitułę i prymat arcyopactwa oraz silny nadzór biskupi dzięki stałym wizytacjom i pełnej jurysdykcji kontrolnej, karnej i konfirmacyjnej ${ }^{9}$. W takich warunkach potężne majątkowo opactwo tynieckie, zamieszkane wówczas przez blisko 60 mnichów i kierujące pięcioma prepozyturami, było w stanie podjąc misję litewską dzięki filii starotrockiej. Praca organizacyjna Wysza i Mścisława przyniosła najsposobniejszą okazję dla tej fundacji.

Wobec wzajemnej niechęci Wysza i Witolda, trzeba przyjąć, że per-

5 P. S czaniecki, Katalog opatów tynieckich, „Nasza Przeszłość” 49 (1978) s. 81 ; T. M. Trajdos, Benedyktyni na Łyścu $z a$ panowania Wtadystawa II Jagietty, ,Roczniki Historyczne” 48 (1982) s. 2.

" P. S c zanie cki, Katalog..., s. 81; tenże, Tyniec, Kraków 1980, s. 79 tenże, Benedyktyni, [w:] Zakony benedyktyńskie $w$ Polsce, Tyniec 1981, s. 52.

7 S. Kijak, Piotr Wysz biskup krakowski, Kraków 1933, s. 62-64.

8 P. Sczaniecki, Benedyktyni..., s. 49; tenże, Katalog..., s. 80 n.; tenże, Tyniec..., s. 79 .

- T. Silnicki, Die Idee der Reform polnischer Benediktinerklöster und das Konstanzer Konzil, Warszawa 1933, s. 9. Była to namiastka niezrealizowanej papieskiej konstytucji „Benedictina” z 1336 r., w której Benedykt XII powoływal jednolitą organizację zakonu z 36 prowincjami i cetralnymi władzami. 
traktacje w sprawie nowego klasztoru prowadził osobiście Mścisław. To prowadzi nas do kwestii chronologii. Pierwszy dokument dotąd zachowany, wzmiankujący o już istniejącym opactwie starotrockim, wystawiła kancelaria Innocentego VII 27 lipca 1405 r., gdzie czytamy, że ,monasterium [...] in Antiquo Troky [...] noviter erectum et fundatum [est]" ${ }^{10}$. Dokument ten nie pozwala określić ściśle daty rocznej fundacji. Brak bowiem przywileju fundacyjnego i dotacyjnego Witolda wywołuje dotąd zupełną dowolność w sądach badaczy, umieszczających fundację w rozmaitych latach początku XV wieku ${ }^{11}$. Tę niepewność umacniały mgliste i sprzeczne przekazy dawnych dziejopisów. Wojciech Wijuk Kojałowicz w ogóle uniknął rocznej datacji ${ }^{12}$, a Stanisław Szczygielski nie znalazł w archiwum tynieckim żadnego odpisu przywileju Witolda. Stąd w swoim katalogu opatów trockich, idąc tropem wzmiankowanego aktu papieskiego, wyraził Szczygielski zdanie, że fundacja nastąpiła „około r. 1405”. Znalazło to na końcu jego dzieła potwierdzenie w przepisanej inskrypcji z fasady kościoła klasztornego w Starych Trokach, gdzie mowa o erekcji, fundacji i dotacji Witolda właśnie w r. $1405^{13}$. Jednakże w pracy Aquila Polono-Benedictina Szczygielski opowiada się za erekcją klasztoru w $\mathrm{r}$. $1410^{14}$, a w Tinecii pominął sprawy trockie przy biogramie Mścisława, umieścił je za to przy wyimaginowanym opacie Henryku III (1421-1430), tłumacząc fundację zachwytem Witolda nad organizacją klasztoru benedyktyńskiego $\mathrm{w}$ trakcie wizyty w Tyńcu po katolickim chrzcie(!) w Krakowie, czyli w r. $1386{ }^{15}$. Wykazano, że postać Henryka Szczygielski zmyślił. W tym okresie (1420-1435) opatem tynieckim był Stanisław Rozkoszka, dobrze poświadczony źródłowo ${ }^{16}$. Bardziej prawdopodobna wydaje się geneza bliższego kontaktu Witolda z Tyńcem, choć decyzja fundacyjna miała miejsce niewątpliwie po r. 1401, tj. po stabilizacji osiągniętej unią wileńsko-radomską.

Oczywiście klasztor istniał już prawnie w połowie roku 1405. Do-

${ }_{10}$ Codex epistolaris Vitoldi, wyd. A. Proch a s ka, Kraków 1882, nr CCCXX; Kodeks dyplomatyczny katedry i diecezji wileńskiej, wyd. J. Fi jałek, W. S e mk o wi c z, Kraków 1948, nr 42 i 43.

${ }_{11}$ Encyklopedia kościelna (wyd. M. Now o d worski, t. 2, Warszawa 1873, S. 157) podaje rok 1410; identycznie J. Kurczewski (Biskupstwo wileńskie, Wilno 1912, s. 253). Kłoczow ski (jw., s. 499) podaje datę: „krótko przed 1403 r.", podobnie (,ok. 1403”) jak Eencyklopedia katolicka (jw., s. 242). Wreszcie P. Sczaniecki (Tyniec..., s. 79) przytacza tradycyjny rok 1405, tak samo jak T. Silnicki (Die Idee..., s. 10). Wyjątkowo błędnie zredagowana jest nota T. Silnickiego, poświęcona tej fundacji, w Historii Kościoła $w$ Polsce (t. $1 \mathrm{cz} .1$, Poznań, s. 379), gdzie mowa (bez daty) o założeniu przez Tyniec ,prepozytury" w Ncwych Trokach (zamiast Starych).

${ }_{12} \mathrm{~W}$. Wijuk Kojałowicz, Miscellanea rerum ad statum Ecclesiasticum in Magno Lithuaniae Ducatu pertinentium, Wilno 1650, s. 104.

13 Szczygielski, Series..., k. A 3, P 2.

14 Tenże, Aquila..., s. 117.

15 Tenże, Tinecia..., s. 83-84.

${ }^{16} \mathrm{Sczaniecki,}$ Katalog..., s. $88-89$. 
wodzi tego jasno pismo papieskie. Nie znam jednak świadectw, na to, by istniał już w r. 1403. Wydaje się, że założenie opactwa starotrockiego niewiele poprzedzało pismo Innocentego VII wzywające do jałmużn na budowę kościoła, mogło więc nastąpić u schyłku 1404 lub na początku 1405 roku.

\section{UPOSAŻENIE}

W omawianym okresie jedynym dobroczyńcą klasztoru trockiego, ofiarodawcą dóbr zapewniających mu egzystencję był sam fundator Witold. Jego dotacji nie wzbogaciły wówczas, przynajmniej w postaci wieczystych zapisów nieruchomości i kapitałów, ani darowizny króla Polski, ani szlachty litewskiej świeżej kreacji, ani mieszczan nowotrockich. Można sądzić, że w r. 1405 fundator przydzielił benedyktynom trockim jedynie prowizoryczne środki utrzymania. Przetrwała bowiem klasztorna tradycja, iż przywilej dotacyjny wystawił wielki książę dopiero w r. $1414^{17}$. $\mathrm{W}$ istocie dokument ten zostal wystawiony przez Witolda $\mathrm{w}$ Trokach na ręce opata Łukasza 14 lutego $1415 \mathrm{roku}^{18}$. Fundator nadaje wieczyście benedyktynom trockim: (1) wszystkie dziesięciny z płodów rolnych z folwarku (dworu) hospodarskiego w Starych Trokach, włącznie $\mathrm{z}$ owsem i sianem; (2) obszar (aream) z dwoma działkami-ogrodami: jedną obok drogi, oddzielającą ów ogród od zamku, drugą położoną koło cmentarza; (3) poletko (agellum) koło dworu; (4) wieś, niegdyś w posiadaniu braci Swigajły (Sungajły) i Mosgajły oraz braci Waśków nad rzeką Waką (wieś przyjęła nazwę Waka), z pełnią praw własności i użytkowania, wraz z jazami na Wace; (5) wieś Obrowo wraz z powinnością danniczą z niej płynącą oraz łowiectwem i wszelkimi użytkami, także i tymi, które wprowadzi się na przyszłość dla polepszenia dochodów klasztoru; (6) jezioro Korwejko, przez które przepływa rzeka, wraz z jazami na tej rzece i resztą pożytków wodnych.

Gdy Szczygielski sumował dobra nadane przez Witolda, okazało się, że nieruchomości pozyskane tuż koło klasztoru można było nazwać wsią Stare Troki, a nadto, że fundator dodał później jeszcze jedną wieś Wszty-

${ }_{17} \mathrm{Szczygielski,}$ Series..., k. P 2. Tak na inskrypcji fasady kościoła w Starych Trokach.

18 Tamże. Kopia wzięta $z$ archiwum Tyńca i wydana w: Kodeks dyplomatyczny klasztoru tynieckiego, wyd. S. S molka, t. 2, Lwów 1875, nr CXLIII. Wydawca uznał ją za dokument podejrzany $z$ uwagi na błędy gramatyczne $w$ dyspozycji oraz dziwną historię dokumentu: $\mathrm{z}$ oryginału mieli oderwać pieczęć Tatarzy napadłszy na opata Bernarda z Wieliczki; w tej postaci dano go do transumptu Zygmuntowi I W r. 1517, natomiast polski przekład wykonano przy transumpcie Zygmunta Augusta (1558). Wydawca przypuszczal więc interpolację z początku XVI w. Jednak przywilej ten, przedrukowany $w$ Kodeksie dyplomatycznym katedry $i$ diecezji wilenskiej (jw., anr 60) ponownie zbadany nie wzbudził w wydawcach żadnych podejrzeń; uznali go za poprawną i wierną kopię oryginału z r. 1415. 
lance ${ }^{19}$. W każdym razie opactwo dostało łącznie trzy wsie, w tym jedną poprzednio bojarską, a jedną hospodarską danniczą, spore grunty w Starych Trokach oraz jezioro, a także rentę naturalną z książęcego folwarku i szczególnie uwydatnione pożytki z rybołówstwa. Wszystko to nie przesłania faktu, że jak na klasztor benedyktyński było to uposażenie skromne, choć znacznie przekraczające ówczesną normę uposażeń parafii w diecezji wileńskiej. Normę tę przekraczało nadanie aż trzech wiosek. Na terenie Auksztoty wielkość wsi, ich zasobność i możliwości dochodowe wykazywały znaczne zróżnicowanie. Wioski bojarskie były na ogół uboższe, słabiej zaludnione. Przeważały wsie dziesięciodymowe, tj. z 10 domami rodzin chłopskich ${ }^{20}$. Natomiast w nadaniu dla opactwa nastąpiła eliminacja typowych dla dotacji parafialnych (w tym dla kanoników pokutnych w Bystrzycy) licznych danin miodowych, zbożowych, osobnych ról uprawnych, karczem i stawów. Fundacja klasztoru utrzymującego się z majątku ziemskiego była kompletną nowością dla Litwy-Auksztoty. Dotąd (do r. 1405) na terenie diecezji wileńskiej doszło wszak jedynie do fundacji żebraczych klasztorów franciszkańskich (Wilno, Lida, Oszmiana, wcześniej Nowogródek), bądź przeznaczonych do pracy parafialnej kanoników pokutnych - marków (Bystrzyca, Miedniki). Trudno więc było przenosić wzory uposażeń benedyktyńskich z tak kompletnie innego pod względem społecznym terenu, jakim była diecezja krakowska. Tymczasem nawyki i wyobrażenia mnichów polskich przewiezionych do Trok niewątpliwie kierowały się ku modelowi tynieckiemu. Uposażenie Witolda pozwalało $\mathrm{z}$ pewnością na ciągłe i sprawne funkcjonowanie wspólnoty konwentu, ale chyba nie tłumiło kłopotów materialnych, jakie stwarzał brak innych donatorów. Z tego powodu wezwanie Innocentego VII w r. 1405 do składania wszelkich jałmużn na budowę klasztoru za cenę ważnych uprawnień penitencjarnych opata (o czym niżej) należy traktować jako istotną pomoc dla mnichów. Niewątpliwie starali się oni zbierać jednorazowe datki, ofiary, subwencje ,pro fabrica”, choć materiał potwierdzający z tego okresu nie przetrwał. Nade wszystko zaś starali się zagospodarować nadany od r. 1415 majątek własny, nie tylko by utrzymać klasztor, ale by uzyskać niezbędny kapitał ze sprzedaży płodów rolnych i hodowlanych.

Klasztor starotrocki objął więc majątek ziemski mniej więcej trzykrotnie większy niż przewidywana norma uposażenia parafii diecezji wileńskiej. Trzeba tu bowiem przypomnieć, że norma ta przewidywała od razu środki utrzymania nie tylko dla plebana, ale i $1-2$ wikarych oraz kleryka prowadzącego szkołę parafialną. Z racji ogólnych przywilejów

$19 \mathrm{Szczygie} 1 \mathrm{ski}$, Aquila..., s. 117.

$20 \mathrm{~J} . \mathrm{O}$ h mańs ki, Powstanie $i$ rozwój latyfundium biskupstwa wileńskiego, Poznań 1963, s. 27-30. 
Kościoła katolickiego na Litwie (potwierdzonych w przywilejach 1413 i 1430 r., a obejmujących też dobra zakonne) klasztor dysponował pełnym immunitetem skarbowym i sądowym ${ }^{21}$.

\section{ORGANIZACJA KLASZTORU}

Klasztor w Starych Trokach pw. Zwiastowania NMP i św. Benedykta został powołany jako opactwo filialne, podporządkowane macierzystemu opactwu w Tyńcu, później zwanemu arcyopactwem ${ }^{22}$. Stąd podwójna podległość opactwa trockiego: z uwagi na ogólny brak egzempcji benedyktynów polskich pozostawało ono pod jurysdykcją biskupów wileńskich, ale wyraźnie określone prawa zwierzchnie zachowało doń stale opactwo tynieckie. Do tego dochodziły kolatorskie uprawnienia fundatora i jego następców na tronie oraz uparcie przypominane przez samych mnichów samorządowe prerogatywy konwentu, wynikłe z reguły św. Benedykta. Prześledźmy ten splot współzależności instytucjonalnych w ciągu pierwszych 30 lat istnienia klasztoru.

Reguła postanawiała, że opata wybiera w nieskrępowany sposób całe zgromadzenie. Opat z kolei posiada pełną władzę nad konwentem, w tym prawo nominacji przeora i innych funkcjonariuszy klasztoru ${ }^{23}$. Zwyczaje (consuetudines) tynieckie wytworzyły organizację kapituły konwentualnej z urzędami podległymi opatowi: przeora, podprzeorzego, kustosza (dla strzeżenia reguły i dyscypliny), klucznika-szafarza, pisarzy koncelarii opackiej i scriptorium, kantorów, organistów ${ }^{24}$. Można oczekiwać, że zapewne ze szczuplejszym personelem ten podział funkcji został przeniesiony do opactwa trockiego. Natomiast rządcy majątków wiejskich klasztoru musieli być wtedy jeszcze wynajętymi ludźmi świeckimi. Podobnie jak w Tyńcu, a bardziej jeszcze z powodu celu pracy nowego klasztoru, w konwencie trockim dominowała grupa ojców-kapłanów oraz diakonów i subdiakonów, którym pomocą służyli bracia konwersi. Nie podobna jednak ustalić liczebności ówczesnego klasztoru trockiego. Wiadomo jedynie, że konwent był całkowicie polski, tak jak zupełnie polski był wtedy klasztor w Tyńcu.

Filialnemu opactwu trockiemu przy zachowaniu macierzystego ustroju, odebrano jednak od początku podstawowe prawo swobodnego wyboru opatów. Wyboru tego dokonywał z własnego grona opat i kapituła

21 Tenże, Dawna Litwa, Olsztyn 1986, s. $102 \mathrm{nn}$.

$22 \mathrm{Sczaniecki}$, Benedyktyni..., S. 48; tenże, Katalog..., s. 78, 83; S z c z ygielski, Tinecia..., s. 238; tenże, Aquila..., s. 117 ; Wijuk Kojałowicz, Miscellanea..., s. 104.

${ }_{23}$ Sw. Benedykt z Nursji, Reguła, Tyniec 1983, roz. LXIV, LXV.

24 S c zaniecki, Tyniec..., s. 52; tenże, Katalog..., s. 78. 
konwentu w Tyńcu ${ }^{25}$. Był to wszakże jedynie obiór kandydata, gdyż ciążył nad mnichami brak egzempcji: elekcję musiał każdorazowo aprobować, a polecanego elekta instytuować prawny zwierzchnik - biskup wileński ${ }^{26}$. Władza biskupa $\mathrm{w}$ zakresie nominacji opackich, nadzoru sądowego i wizytacyjnego była wówczas surowo obserwowana. Do tego wreszcie dochodziła prezenta kolatora, z którym konwent tyniecki musiał uzgadniać kandydata, a biskup wileński uzależniać swą konfirmację. W praktyce wyglądało to następująco. Opata Łukasza rządzącego Trokami w okresie około 1405 (raczej po 1405) - 1415 wybrał opat i kapituła z Tyńca spośród kapłanów tynieckiego konwentu. Był to polski szlachcic, w r. 1406 zapisany w Akademii w gronie scholarów benedyktyńskich, od młodości wczesnej chowany w Tyńcu ${ }^{27}$. Dziejopis zakonu zwracał uwagę na jego wiedzę teologiczną, surową obserwację reguły, skrupulatność dewocji, nadzór nad liturgią konwentualną. Nadmienia jednak, że u schyłku życia zupełnie tego zaniechał. To na jego ręce Witold dotował klasztor, bo niewątpliwie opat odpowiadał mu zupełnie. Łukasz zmarł w grudniu r. 1415.

Rok później zjawił się nowy opat - Wojciech Żegota, którego sposób nominacji dokładnie określa pismo Witolda z 24 XII 1416 r. ${ }^{28}$ Tyniecki kapłan został obrany przez opata i konwent Tyńca (,,canonice electum, praesentatum et transmissum"), ale na wyraźne życzenie Witolda, który obiór przyjął i prezentował biskupowi wileńskiemu Piotrowi do zatwierdzenia i legalnej instytucji na krześle opackim w Trokach. Hospodar nie omieszkał zaznaczyć, że jego prawa kolatorskie wynikają też z faktu, iż opactwo założył ,in patrimonio nostro in Antiquis Troki”. Ale w r. 1416 uszanowano właściwość uprawnień opactwa macierzysteg.o, kolatora i biskupa. Tymczasem w r. 1423 Wojciech Żegota znużony, jak przypuszcza Szczygielski, troskami zarządu gospodarczego, a może pragnąc powrócić do ciszy zakonnej kontemplacji, sam ustąpił z godności. Nastąpił niespodziewany wakans. Wówczas inicjatywę przejawił konwent trocki, obierając samodzielnie jako opata tymczasowego (abbas surrogatus) miejscosowego mnicha Jakuba. Na prośbę konwentu zatwierdził go i intronizował jako opata biskup wileński Piotr. Tyniec został więc wyeliminowany, brak też danych o stanowisku Witolda. Broniąc prerogatyw tynieckich, opat Stanisław Rozkoszka napisał 13 października 1424 r. do nowego biskupa Wilna Macieja o samowolnej elekcji Jakuba, zaznaczając, że obecnie wraz z kapituła zgromadzenia tynieckiego zatwierdza ten wybór

${ }_{25} \mathrm{Szczygie}$ lski, Series..., k. P 2.

${ }^{26} \mathrm{~F}$. Bog dan, Sprawa egzempcji benedyktynów $w$ Polsce średniowiecznej, „Nasza Przeszłość” 9 (1959) s. 77; S c zaniecki, Benedyktyni..., s. 47, 49.

${ }^{27} \mathrm{Szz} z$ yg ielski, Series...; S czaniecki, Katalog..., s. 78.

28 Kodeks dyplomatyczny katedry $i$ diecezji wileńs,kiej, jw., $\mathrm{nr}$ 69; Kodeks dyplomatyczny klasztoru tynieckiego, jw., nr CXLIV; Szczygielski, Series... 18 - Analecta Cracoviensia 
i upoważnia nowego opata do pełnienia funkcji ${ }^{29}$. Sprawa ta poważnie naruszyła uprawnienia opactwa macierzystego, pokazując, że mnisi starotroccy mogli z powodzeniem uzyskać konfirmację własnych decyzji personalnych wprost u biskupa wileńskiego. Podległość wobec Tyńca została jednak utrzymana dalej w sposób trwały aż do kasaty klasztoru w r. 1842. Opat Jakub rządził w Starych Trokach jakieś 20 lat, czyli do około 1443 r. $^{30}$, zamykając więc okres, który tu omawiamy.

\section{FUNKCJE KLASZTORU}

Bez wątpienia podtrzymano $w$ Starych Trokach system życia konwentualnego z ówczesnego Tyńca, tj. dbałość o wspólną liturgię, skupienie na wartościach indywidualnych medytacji i pobożnych lektur, widoczne w okresie rządów Mścisława ${ }^{31}$. Interesowano się też wówczas próbami formacji duchowej zakonu idącymi z opactwa w Melk ${ }^{32}$. Opactwo starotrockie musiało jednak przyjąć na siebie w kraju świeżo ewangelizowanym obowiązki misyjne i duszpasterskie. Te cele są wzmiankowane $\mathrm{w}$ dokumentach tego czasu, poświęconych klasztorowi. W piśmie Witolda z r. 1416 jako powód fundacji podaje się: ,pro augmento sanctae fidei catholicae inter neophytos nostrarum terrarum"; podobnie cele krzewienia wiary wspomina opat tyniecki w piśmie z r. 1424. Według Szczygielskiego intensywny apostolat katolicki prowadził opat Eukasz. Przekazy te należy jeđnak traktować $\mathrm{z}$ wielką ostrożnością. Benedyktyni diecezji krakowskiej, szczególne w swoich mniejszych prepozyturach i parafiach inkorporowanych, byli wtedy zdatni do pracy duszpasterskiej, choć nadal uważano, że przeczy ona regule i głuszy prawidłowy kontemplacyjno-liturgiczny model monastycyzmu. Klasztor starotrocki uzyskał jednak lokalizację właściwie rezydencjonalną, pod okiem Witolda, a o efektach jego wysiłków misyjnych tego czasu nic naprawdę nie wiemy. Wokół mieszkała niedawno ochrzczona ludność katolicka, wiejska i szlachecka, nieopodal kwitł katolicki dwór Witolda, a w Nowych Trokach poszerzał się krąg mieszczaństwa częściowo przynajmniej o starszej metryce katolickiej, gdyż mieszkali tam także Polacy i Niemcy. Charakter ich kontaktów z mnichami starotrockimi nie jest do odtworzenia w pierwszej ćwierci XV w. Warto wszakże nadmienić, że w sąsiednim mieście istniała oczywiście parafia katolicka kreacji Witolda.

Benedyktyni starotroccy musieli liczyć się też z miejscowym, przeważnie polskim etnicznie klerem parafii Nowych Trok od około 1409 r.,

\footnotetext{
${ }^{29}$ Kodeks dyplomatyczny katedry..., jw., nr 89; Kodeks dyplomatyczny klasztoru tynieckiego, jw., $\mathrm{nr}$ CLIV.

so $\mathrm{Szczyg}$ ielski, Series...

81 S c zanie cki, Katalog..., s. 78.

$32 \mathrm{Silnicki}$, Die Idee..., s. $14 \mathrm{n}$.
} 
a wiejskiej parafii Starych Trok od r. 1400, obficie dotowanym, dobrze wyposażonym do pracy duszpasterskiej, cieszącym się (jak na całej Litwie) pełnym immunitetem i absolutną własnością dóbr ${ }^{33}$. W Nowych Trokach działała już w r. 1409 parafialna szkoła miejska, ucząca wedle niekompletnego programu trivium, a także języków polskiego i niemieckiego na tyle skutecznie, że do Akademii Krakowskiej przybywają stąd studenci już od 1419 r. Co więcej, choć szkoła w Starych Trokach znana jest od r. 1472, to i stąd zjawia się pierwszy student Akademii już w r. 1413. Czy współpraca zakonu z parafiami była zgodna, czy konfliktowa, nie podobna ocenić wobec braku materiału w tym okresie, ale na ogół plebani i wikariusze parafii starali się ograniczyć aktywność duszpasterską mnichów na swoim terenie, szczególnie zakonu o formacji nie predestynującej do tego typu pracy. Witold uważał wszakże instytucje kościelne za ważne narzędzie polityczne, m.in. w planach umacniania suwerenności Wielkiego Księstwa poprzez budowę prowincji kościelnej odseparowanej od Polski. Wyraziłem już wcześniej pogląd, że do tego celu powziął myśl wykorzystania także benedyktynów z klasztoru starotrockiego ${ }^{34}$. Wykazuje to cytowane już pismo papieskie z r. 1405 . Otóż pierwszym opatem starotrockim z prezenty Witolda, pominiętym $\mathrm{w}$ katalogu Szczygielskiego, był Borzysław, występujący równocześnie jako biskup kijowski ${ }^{35}$.

Wysunięcie tej osoby na katedrę kijowską przez Witolda było aktem wyzwania wobec Polski, polskiego Kościoła, ale i w sensie prawa kościelnego zwykłą uzurpacją, gdyż katedrę tę obsadzali już wcześniej biskupi rekrutujący się z polskich dominikanów siedzących w konwencie kijowskim, zmierzający do sprzężenia tej nowej diecezji z kościelną prowincją halicko-lwowską. Nastąpiło to oficjalnie w r. 1412 i przesądziło o związku katolickiej diecezji kijowskiej z hierarchią Kościoła w Polsce. Witold marzył o skutku odwrotnym - powołaniu litewskiej metropolii kościelnej, której podporządkowano by niewątpliwie diecezje leżące w granicach Wielkiego Księstwa, czyli m. in. na Wołyniu i Kijowszczyźnie. W walce o kościelny Kijów posłużył się więc opatem starotrockich benedyktynów z klasztoru uzależnionego wyłącznie od łask benefaktorskich hospodara, a więc uległego jego woli. Borzysław, tytułowany przez Innocentego VII biskupem kijowskim, otrzymał przywilej udzielania absolucji i nakładania pokuty nawet $\mathrm{w}$ sprawach zastrzeżonych dla papiestwa, w zamian za jałmużny na budowę klasztoru. Tytulacja Borzysława i cały kryjący się za tym plan Witolda niewątpliwie zostały rychło sprosto-

* J. Ochmański, Dawna Litwa..., s. -114, 117, 121.

34 T. M. Trajdos, Kościót katolicki na ziemiach ruskich Korony i Litwy za panowania Władystawa II Jagiełły (1386-1434), Wrocław-Warszawa-KrakówGdańsk 1983, s. 57 n.

${ }^{85}$ Por. Sczaniecki. Tyniec..., s. 79. 
wane przez dygnitarzy Korony wobec Rzymu, gdyż wkrótce potem biskupstwo kijowskie jako sufragania Lwowa spoczywa już niepodważalnie w rękach polskich dominikanów. Następuje też bardzo szybka zmiana na trockim stolcu opackim. Szczygielski, nie znający pisma Innocentego VII, uważał za opata Łukasza i początek jego rządów kładł na około 1405 r. Akcja Borzysława zakończyła się więc fiaskiem, jak i reszta mocarstwowych aspiracji Witolda. Można natomiast suponować, że w genezie starotrockiej fundacji leżały co najmniej w równym stopniu polityczne zamysły wielkiego księcia w odniesieniu do samodzielnej organizacji Kościoła na Litwie, co zadania apostolatu katolickiego w diecezji wileńskiej ${ }^{36}$.

\section{DIE STIFTUNG DER BENEDIKTINERABTEI STARE TROKI}

\section{Zus a m m enf as s ung}

Im Jahre 1405 stiftete der Großfürst Witold in Stare Troki die Benediktinerabtei Mariä Heimsuchung und des hl. Benedikt. Stare Troki waren unweit der fürstlichen Residenz gelegen. Die Benediktiner holte Witold von Tyniec bei Krakau. Aus diesem Grunde bestand der Konvent in Stare Troki aus polnischen Mönchen und verblieb eine Zweigniederlassung der Abtei in Tyniec. Auch den Abt erwählte das Ordenskapitel in Tyniec. Erst danach bestätigte der Wilnauer Bischof die Ernennung, da die polmischen Benediktiner im XV. Jh. keine Exemption besaßen und der Jurisdiktion der Diözesanbischöfe unterlagen.

Die Stiftung in Stare Troki kam nicht allein auf Witolds Wunsch hin zustande, der sich die Kollatur vorbehielt, sondern auch dank der Unterstützung des Abts von Tyniec, Mścisław, und dessen Protektors, des Krakauer Bischofs Peter Wysz, denen das Problem der intensiven Christianisierung Litauens am Herz lag. Im Jahre 1415 überwies Witold der neuen Abtei eine Dotierung (u. a. drei Dörfer). Andere Donatoren besaß die Abtei damals noch nicht.

Außer zu religiösen Zwecken sollte das Kloster in Stare Troki ads einer der Faktoren dienen, die die Bestrebungen Witolds unterstützen sollten, im Großfürstentum Litauen eine unabhängige Kirchenprovinz zu errichten. Der erste Abt, Borzysław, wurde von ihm zum Bischof von Kiew erhoben, als Opposition den dortigen Missionsbischöfen gegenüber, die polnische Dominikaner waren und diese Diözese mit der polnischen Kirchenprovinz in Lemberg liieren wollten. Witolds Pläne scheiterten.

${ }^{36}$ Uzupetnienie do s. 245: Klasztor benedyktynów założono na ruinach zamku Giedymina na wzgórzu-grodzisku w Starych Trokach (por. A. M e d o n is, Trakai, Wilno 1966, s. 8-10, 15). Po najeździe Krzyżaków w r. 1375 Kiejstut założył parę kilometrów dalej na półwyspie jeziora Galue Nowe Troki i zamek-rezydencję z obronnym podzamczem. W r. 1383 zamek ten złupili Krzyżacy, a w r. 1391 spalili i zamek, i miasto. Odbudowując miasto na początku XV w. wzniósł Witold na wyspie jeziora nowy gotycki, ceglany zamek - swą ulubioną siedzibę. 